\title{
Picoeukaryote Plankton Composition off West Spitsbergen at the Entrance to the Arctic Ocean
}

\author{
Estelle S. Kilias, Eva-Maria Nöthig, Christian Wolf \& Katja Metfies \\ Alfred Wegener Institute Helmholtz Centre for Polar and Marine Research, 27570, Bremerhaven, Germany
}

\begin{abstract}
Keywords
454-pyrosequencing; biodiversity; biogeography; microbial diversity; next generation sequencing; phytoplankton.

\section{Correspondence}

E. S. Kilias, Alfred Wegener Institute for Polar and Marine Research, Am Handelshafen 12, 27570 Bremerhaven, Germany Telephone number: + 49047148311384 ; FAX number: + 4904714831 1149; e-mail: Estelle.Kilias@awi.de
\end{abstract}

Received: 10 October 2013; revised 3 April 2014; accepted April 3, 2014.

doi:10.1111/jeu.12134

\section{ABSTRACT}

Investigation of marine eukaryotic picoplankton composition is limited by missing morphological features for appropriate identification. Consequently, molecular methods are required. In this study, we used 454-pyrosequencing to study picoplankton communities at four stations in the West Spitsbergen Current (WSC; Fram Strait). High abundances of Micromonas pusilla were detected in the station situated closest to Spitsbergen, as seen in surveys of picoplankton assemblages in the Beaufort Sea. At the other three stations, other phylotypes, affiliating with Phaeocystis pouchetii and Syndiniales in the phylogenetic tree, were present in high numbers, dominating most of them. The picoplankton community structures at three of the stations, all with similar salinity and temperature, were alike. At the fourth station, the influence of the East Spitsbergen Current, transporting cold water from the Barents Sea around Spitsbergen, causes different abiotic parameters that result in a significantly different picoeukaryote community composition, which is dominated by M. pusilla. This observation is particularly interesting with regard to ongoing environmental changes in the Arctic. Ongoing warming of the WSC could convey a new picoplankton assemblage into the Arctic Ocean, which may come to affect the dominance of $M$. pusilla.
PICOPLANKTON cells, covering a size range of $0.2-2.0$ or $3.0 \mu \mathrm{m}$ (Sieburth et al. 1978; Vaulot et al. 2008), predominate in protist assemblages of oligotrophic waters, reaching abundances of $10^{2}-10^{4}$ cells/ml (Ishizaka et al. 1997; Li 2009; Massana 2011). In the Arctic Ocean, autotrophic representatives of the picoplankton are significant primary producers (Degerlund and Eilertsen 2010). Their large surface-area-to-volume ratio enables effective nutrient uptake and hinders rapid sinking ( $\mathrm{Li}$ et al. 2009). Richardson and Jackson (2007) suggested that autotrophic picoplankton may account for more oceanic carbon export to deeper waters than previously recognized. The emerging importance of these minute eukaryotes for marine ecosystem functioning has resulted in an increase in studies of their diversity (Diez et al. 2001; Lopez-Garcia et al. 2001; Lovejoy et al. 2007; Massana 2011; Massana et al. 2004a; Moon-van der Staay et al. 2001; Not et al. 2004, 2009; Potvin and Lovejoy 2007; Romari and Vaulot 2004; Vaulot et al. 2008; Worden 2006).

The application of molecular methods has revolutionized our understanding of the microbial world. 454-pyrosequencing is a high-throughput method that delivers large numbers of sequence reads in a single experiment (Huse et al. 2008; Medinger et al. 2010). The method was first introduced by Sogin et al. (2006) to characterize microbial communities in the marine environment. The investigation of short hypervariable regions of the SSU rRNA, in which the V4 is the largest and most complex, revealed tremendous hidden diversity in protist communities, particularly among the smallest protists (Lopez-Garcia et al. 2001; Moon-van der Staay et al. 2001). As a result, picoplankton gained increased attention and was found to dominate in photosynthetic and heterotrophic processes over much of the world's oceans (Whitman et al. 1998).

To date, knowledge of picoplankton community compositions is limited. Current research assumes that representatives can be found in all major taxonomic algal classes (Simon et al. 1994; Veldhuis et al. 1997, 2005). Picoplankton genera like Ostreococcus were observed in abundances great enough $\left(>10^{5}\right.$ cells $/ \mathrm{ml}$ ) to produce small "blooms" off the coast of Southern California (Countway and Caron 2006). Thus, temperature can have a large influence on picoplankton diversity and distribution. The Temperature Size Rule, which implies an inverse relationship between temperature and body size is known to hold for protists just as well as for bacteria and metazoa. Protist 
size has also been seen to decrease with decreasing surface nutrient concentrations (Atkinson 1994; Atkinson et al. 2003; Bopp et al. 2005; Daufresne et al. 2009; Moran et al. 2010; Peter and Sommer 2012). The Canadian Basin has been the focus of several molecular protist diversity studies (Lovejoy et al. 2004, 2006, 2007, 2011; Lovejoy \& Potvin 2011). In the Beaufort Sea, molecular surveys of autotrophic, picoeukaryote communities reported strong dominance of Micromonas pusilla, particularly of a pan-Arctic, cold-adapted ecotype (Lovejoy et al. 2007; Marin and Melkonian 2010). In contrast, comprehensive information on picoplankton community structure is missing in the Eurasian part of the Arctic Ocean.

A molecular investigation of picoeukaryotic plankton at the entrance to the Arctic Ocean would be of great importance for future plankton studies with regard to expected climate change. The Fram Strait is the only deep-water connection to the central Arctic Ocean. The hydrography of the eastern Fram Strait is characterized by inflow of warm and saline Atlantic Water (AW) via the West-Spitsbergen Current (WSC). Most of the ongoing temperature increase in the Arctic Ocean is attributed to warming and strengthening of the WSC (Beszczynska-Möller et al. 2012; Schauer et al. 2004). This may also result in the northward transport of different AW protist communities. Generally, water masses are found to affect the dispersion of small microbes, acting as physical boundaries by virtue of their varying densities (Galand et al. 2009). Fram Strait is not solely influenced by the WSC. Another current, the east Spitsbergen Current (ESC) transports cold Arctic water from the Barents Sea northwards.

The sampling sites of this study are part of a long-term observatory, named HAUSGARTEN, by the Alfred Wegener Institute (Soltwedel et al. 2005). Here, the picoplankton community structure is of great importance because picoplankton can account for a large proportion of the biomass (K. Metfies., unpubl.data). Our data on picoeukaryotes present the first of their kind in the Arctic region. Therefore, the data will serve as a baseline for picoplankton diversity at the HAUSGARTEN observatory and in the central Arctic Ocean. In this study, we want to assess if there are parallels in the picoplankton community structures of the eastern Fram Strait and Canadian Basin. Our study further includes an assessment of the permeability of sequential filtration at one reference station. The current debate on the inclusion of possible false positive picoplankton species in picoplankton diversity studies, as artifacts of cell breakage or sloppy feeding, makes such an evaluation reasonable.

\section{MATERIAL AND METHODS}

\section{Sampling area}

The sampling was performed during the ARK-XXIV/2 expedition, on-board RV Polarstern from 11 to 18 July 2009, at the deep-sea long-term observatory HAUSGARTEN (HG) of the Alfred Wegener Institute Helmholtz Centre of Polar and Marine Research. The observatory is located in the
Fram Strait at $78-80^{\circ} \mathrm{N}$ and $3-7^{\circ} \mathrm{E}$, close to the coast of Svalbard (Fig. 1). Water samples were taken from four different stations (HG1, HG4, HGN4 and HGS3) in the euphotic zone at the chlorophyll maximum (Chl max), by collecting seawater with $12 \mathrm{~L}$ Niskin bottles deployed on a rosette equipped with CTD sensors for temperature and salinity determinations (Table 1). Two liter water subsamples were transferred into polycarbonate bottles for subsequent filtration. To obtain the picoplankton fraction, protist cells were collected immediately by sequential fractionation at 200 mbar, through Isopore Membrane Filters (Millipore, Billerica, MA) with pore sizes of $10 \mu \mathrm{m}, 3 \mu \mathrm{m}$, and $0.4 \mu \mathrm{m}$. Finally, the filters were transferred into microcentrifuge tubes and stored at $-80{ }^{\circ} \mathrm{C}$ until further processing. Analysis of the picoplankton community structure was carried out at all four stations, while the permeability of sequential filtration was assessed at one station (HG4).

\section{DNA extraction}

After initial incubation of the filters in the lysis buffer provided, DNA was extracted with the E.Z.N.A TM SP Plant DNA Kit (Omega Bio-Tek, Norcross, GA) following the manufacturer's instructions. Genomic DNA was eluted from the column with $60 \mu$ l elution buffer. DNA concentration was determined with a NanoDrop 1000 system (Thermo Fisher Scientific, Pittsburgh, PA). The extracts were stored at $-20^{\circ} \mathrm{C}$ until further processing.

\section{4-pyrosequencing}

Four picoplankton, one nanoplankton, and one microplankton sample were analyzed by 454-pyrosequencing. The nanoplankton and microplankton samples serve as control to assess the quality of the sequential filtration. We amplified $\sim 670$ bp of the 18S rDNA containing the V4 region with the primer sets 528F (GCG GTA ATT CCA GCT CCA A) and 1055R (ACG GCC ATG CAC CAC CAC CCA T) (modified after Elwood et al. 1985). PCR reaction and purification was conducted as described in Kilias et al. (2013). Pyrosequencing was performed on a Genome Sequencer FLX system (Roche, Mannheim, Germany) by GATC Biotech AG (Konstanz, Germany).

\section{4-pyrosequencing - data analysis}

Reads shorter than 300 bp were excluded from the analysis to guarantee the analysis of the whole $V 4$ region ( 230 bp; Nickrent and Sargent 1991), increasing the quality of raw sequences. Recent critical studies of denoising pipelines have shown that loading data in developed pipelines can transform final sequences, inconsistent with the spectrum of errors (Comeau et al. 2013; Gaspar and Thomas 2013). In view of this, we processed our raw data by applying single tools. Sequences longer than $670 \mathrm{bp}$ (expected amplicon size) with more than one uncertain base $(\mathrm{N})$ and with homopolymers of six or more successive bases were also removed. Chimeric sequences were detected using the UCHIME software (Edgar et al. 2011), and excluded from further analysis. Operational taxonomic 


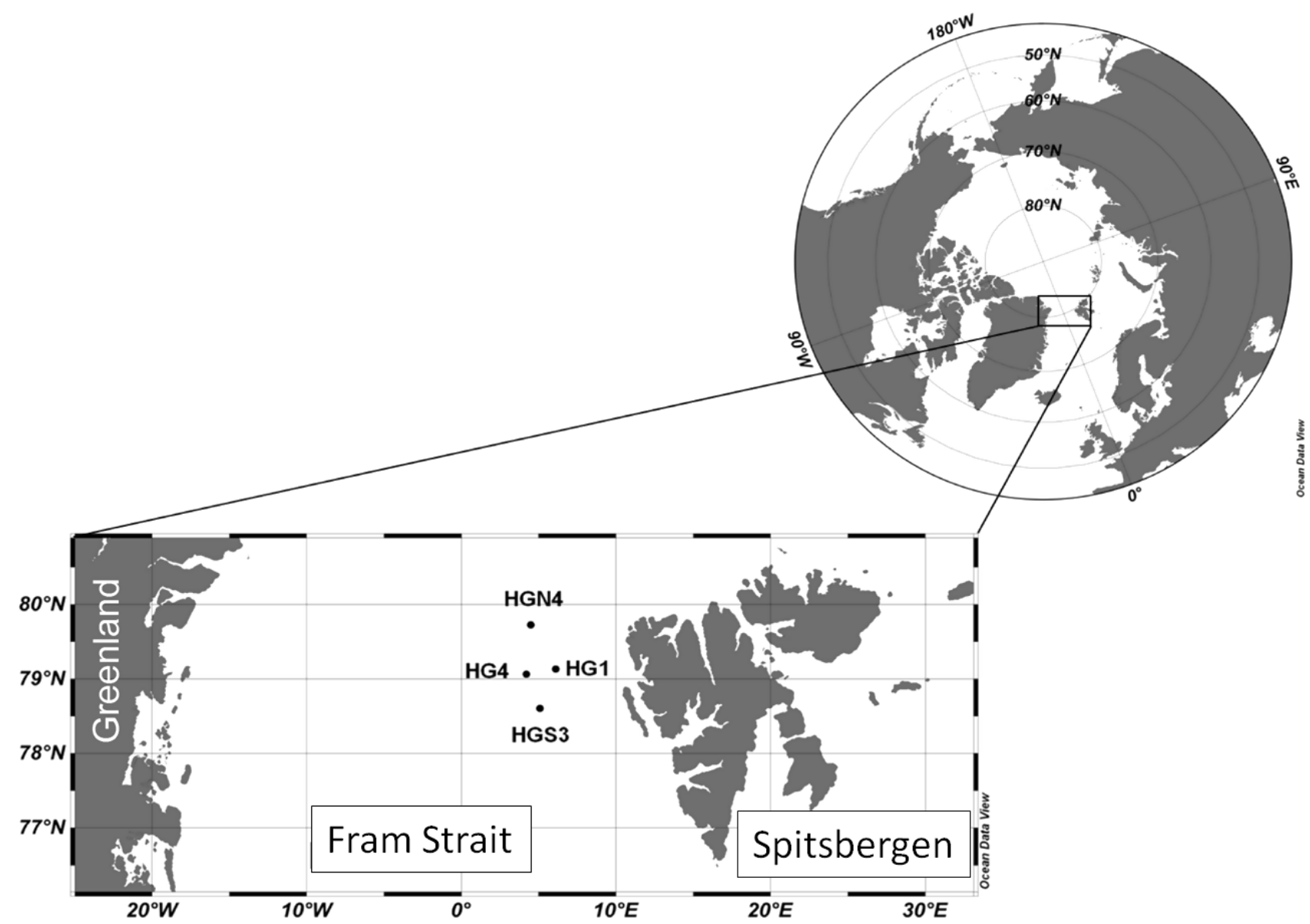

Figure 1 Map of the investigation area: deep-sea long-term observatory "HAUSGARTEN". Water samples of the four sampling sites were taken in July 2009 at the chlorophyll maximum.

Table 1. Coordinates and abiotic conditions at the sampling site, taken in a time slot of $7 \mathrm{~d}$ in July 2009 ( $T=$ temperature)

\begin{tabular}{lcccccc}
\hline Station-ID & $\begin{array}{c}\text { Longitude } \\
{ }^{\circ} \mathrm{E}\end{array}$ & $\begin{array}{c}\text { Latitude } \\
{ }^{\circ} \mathrm{N}\end{array}$ & $\begin{array}{c}\text { Sampling } \\
\text { depth }(\mathrm{m})\end{array}$ & $\begin{array}{c}T \\
\left({ }^{\circ} \mathrm{C}\right)\end{array}$ & $\begin{array}{c}\text { Salinity } \\
(\mathrm{PSU})\end{array}$ & $\begin{array}{c}\text { Ice } \\
\text { cover } \\
(\%)\end{array}$ \\
\hline $\begin{array}{c}\text { HG1 } \\
\text { (East) }\end{array}$ & 6.102 & 79.134 & 15 & 1.9 & 34.4 & 0 \\
$\begin{array}{c}\mathrm{HG} 4 \\
(\text { West) }\end{array}$ & 4.196 & 79.067 & 25 & 4.2 & 34.9 & 50 \\
$\begin{array}{c}\mathrm{HGN4} \\
(\text { North) }\end{array}$ & 4.478 & 79.729 & 30 & 5.9 & 35.1 & $30-50$ \\
$\begin{array}{c}\text { HGS3 } \\
\text { (South) }\end{array}$ & 5.070 & 78.607 & 40 & 6.7 & 35 & 0 \\
\hline
\end{tabular}

The geographical distances between the stations are as follows: $\mathrm{HG} 1 /$ HG4 ( 40.8 km), HG1/HGN4 ( 74.0 km), HG1/HGS3 (62.6 km), HG4/ HGN4 (73.8 km), HG4/HGS3 (54.5 km), and HGN4/HGS3 (125.4 km).

units (OTUs) were generated by clustering the remaining high-quality reads with the Lasergene Seqman Pro software package (DNAStar, Madison, WI). Following the studies of Kunin et al. (2010), Miranda et al. (2012) and
Behnke et al. (2011), we applied a threshold of $97 \%$ and match size of $50 \mathrm{bp}$ to minimize the danger of diversity overestimation and to allow comparison with published data. All singletons, defined as OTUs composed of uniquely occurring sequences, were removed to evade possible errors induced during the sequencing process. Table 2 shows an overview of the 454-pyrosequencing, presenting the numbers of raw reads, the numbers of unqualified and removed reads, and the final read numbers, including the OTU numbers after clustering. The consensus sequences were placed into a reference tree built from 1,200 high-quality sequences from the SILVA reference database (SSU Ref 108), containing representatives of all main eukaryotic phyla. This involved the use of PhyloAssigner software (Vergin et al. 2013). Sequences that affiliated with nonprotist phyla in the tree were excluded from further analysis. PhyloAssigner allows a quantification of the likelihood of read placements in the phylogenetic tree. In this study, we used a threshold of $80 \%$ as the taxonomic level at which a sequence read can be annotated. It is only possible to annotate a sequence with high taxonomic resolution if a reference sequence is available. This is very often not the case. Thus, many sequences can only be reliably annotated at higher 
Table 2. 454-pyrosequencing data processing for the picoplankton analysis and for the evaluation of size fractionation quality

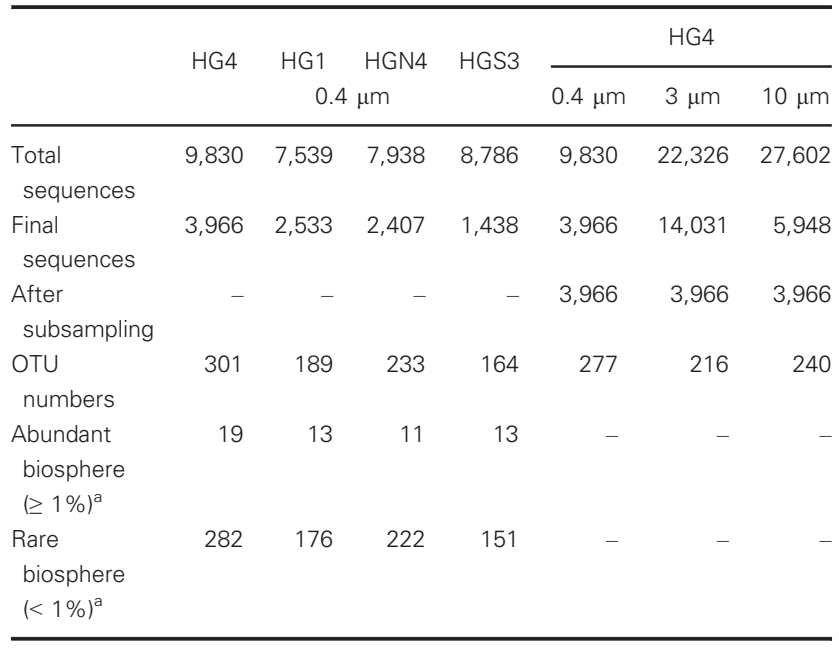

${ }^{\mathrm{a} C}$ Classification after Sogin et al. (2006).

taxonomic levels. Sequences that affiliated with nonprotist phyla in the tree were excluded from further analyses. The remaining reads were aligned using the SILVA aligner (Pruesse et al. 2007) and placed into a reference database tree containing around 50,000 eukaryotic sequences from the SILVA reference database (SSU Ref 108), to refine the assignment.

Random subsampling to the minimum sequence number (after quality processing) was carried out for the evaluation of filtration permeability at HG4, because sequencing depths differed by several magnitudes. The subsampled data were processed as described above. The concurrent clustering of all three size fractions $(>10 \mu \mathrm{m}, 10$ to $3 \mu \mathrm{m}$ and 3 to $0.4 \mu \mathrm{m}$ ) in OTU has the advantage of yielding identical descriptions for identical phylotypes. The 454-pyrosequencing reads were deposited at GenBanks's Short Read Archive (SRA) under the accession no. SRA058841.

\section{RESULTS}

\section{Environmental characteristics}

The HAUSGARTEN sampling stations are distributed in a cross pattern (Fig. 1). HGN4 is situated in the north, HGS3 in the south, HG4 in the west and HG1 in the east. Temperature was coolest in the east $\left(\mathrm{HG} 1 ; 1.9^{\circ} \mathrm{C}\right)$ and warmest in the south $\left(\mathrm{HGS} 3 ; 6.7^{\circ} \mathrm{C}\right)$. The western and northern stations showed $4.2^{\circ} \mathrm{C}$ and $5.9^{\circ} \mathrm{C}$. The range of salinity values was between 34.4 PSU (HG1) and 35.1 PSU (HGN4) (Table 1). Sea ice was unevenly distributed during the sampling period, being absent from stations $\mathrm{HG} 1$ and HGS3 and constituting moderate coverage (30-50\%) at stations HGN4 and HG4.

\section{Picoplankton diversity}

Sequencing of the four picoplankton communities showed similar sequencing depths that comprised on average
8,523 reads. Filtering of low quality reads removed between $60 \%$ and $84 \%$ of the initial read number (Table 2). The clustering in OTUs ( $97 \%$ threshold) resulted in a total of 301 OTUs at station HG4, 189 OTUs at HG1, 233 OTUs at HGN4, and 164 OTUs at HGS3. OTUs can be classified into those few that were represented by many reads (abundant taxa; $\geq 1 \%$ of total reads), and of the remaining many that were represented by just a few reads (rare taxa; $<1 \%$ of total reads). Richness of the abundant biosphere ranged from 11 (HGN4) to 19 (HG4) OTUs, and 151 (HGS3) to 282 (HG4) OTUs in the rare biosphere.

In Figure 2, different OTUs are grouped according to their taxonomic affiliations to major phylogenetic groups as haptophytes, chlorophytes, cryptophytes, stramenopiles, dinoflagellates, syndiniales, and ciliates. The average picoplankton community structure over all four sampling sites was dominated by chlorophytes ( 24\%), syndiniales $(\sim 22 \%)$, and haptophytes $(\sim 21 \%)$. Chlorophytes dominated the picoplankton community at $\mathrm{HG} 1$ and contributed $59.6 \%$ to the total assemblage. Haptophytes and syndiniales shared the dominance of HG4 at 31\% and 22\%. Likewise, HGS3 was characterized by abundant haptophytes $(26.1 \%)$ and syndiniales $(30 \%)$, while the maximum proportions observed at HGN4 were of syndiniales and dinoflagellates ( $30 \%$ each). Picoplankton stramenopiles, in contrast, were evenly distributed across the four sampling sites, ranging between $11.6 \%$ and $15.5 \%$. A scan of the rare biosphere reveals stable relative abundances of the major taxonomic groups and a dominance of syndiniales phylotypes. The abundant biosphere, in contrast, is more variable.

Table 3 presents a phylotype (OTU)-specific taxonomic apportionment of the abundant biosphere, including phylotypes that matched with sequences in the database. Phylotypes were not exclusively observed in abundant proportions at all stations. Of 22 phylotypes, only two Phaeocystis pouchetii and Bathycoccus prasinos were ubiquitously abundant, comprising $9.3 \%$ and $9.5 \%$ at HG1, 29.6\% and $5.4 \%$ at HG4, $13.9 \%$ and $1.3 \%$ at

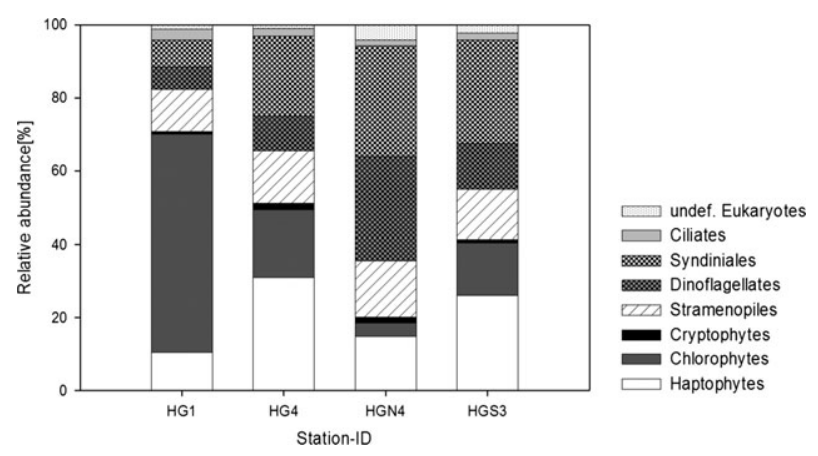

Figure 2 Picoplankton community composition at the four sampling stations. Histogram is presented for the major taxonomic groups (haptophytes, chlorophytes, cryptophytes, stramenopiles, dinoflagellates, ciliates, and undefined eukaryotes) and presents the relative abundances $(\%)$ in the sequence data. 
Table 3. Distribution of picoplankton phylotypes in the abundant biosphere $(\geq 1 \%$ of the total reads)

\begin{tabular}{|c|c|c|c|c|}
\hline & HG1 & HG4 & HGN4 & HGS3 \\
\hline \multicolumn{5}{|l|}{ Stramenopiles } \\
\hline Undef. Chrysophyte & 1.3 & 4.0 & - & - \\
\hline MAST I & - & 1.2 & - & - \\
\hline MAST III & - & 1.2 & - & - \\
\hline Bolidomonas pacifica & 3.1 & 1.3 & - & - \\
\hline Undef. Pelagophyte & - & - & - & 1.9 \\
\hline \multicolumn{5}{|l|}{ Alveolates } \\
\hline Undef. Alveolate & - & 6.0 & - & - \\
\hline Undef. Dinophyte & - & - & 22.4 & - \\
\hline Prorocentrales & 4.1 & - & 2.1 & - \\
\hline Gymnodiniales 1 & - & - & - & 1.5 \\
\hline Gymnodiniales 2 & - & - & 1.6 & - \\
\hline Syndiniales 1 & - & 1.5 & 1.2 & - \\
\hline Syndiniales 2 & - & 2.3 & - & - \\
\hline Syndiniales 3 & - & - & 1.2 & - \\
\hline Syndiniales 4 & - & - & - & 1.1 \\
\hline Ciliate 1 & 2.7 & 1.9 & 1.3 & - \\
\hline \multicolumn{5}{|l|}{ Haptophytes } \\
\hline Phaeocystis pouchetii & 9.3 & 29.6 & 13.9 & 25.2 \\
\hline \multicolumn{5}{|l|}{ Chlorophytes } \\
\hline Micromonas pusilla 1 & 45.0 & 6.2 & - & 6.3 \\
\hline Micromonas pusilla 2 & 2.3 & 2.7 & - & 2.0 \\
\hline Bathycoccus prasinos & 9.5 & 5.4 & 1.3 & 3.0 \\
\hline \multicolumn{5}{|l|}{ Undefined Eukaryotes } \\
\hline Undef. Eukaryote 1 & - & - & 1.9 & - \\
\hline Undef. Eukaryote 2 & - & - & 1.1 & - \\
\hline Undef. Eukaryote 3 & - & - & - & 2.2 \\
\hline
\end{tabular}

Phylotypes that are listed matched with sequences in the quality trimmed SSU Ref 108 database (high taxonomic resolution). All data are presented in relative abundance (\%).

HGN4, and $25.2 \%$ and $3 \%$ at HGS3. The other 20 phylotypes were either rare or missing at one or more stations. The abundant biosphere at HG1 further consisted of two stramenopiles (Chrysophyte 1: $1.3 \%$ and Bolidomonas pacifica: $3.1 \%$ ), two alveolates (Prorocentrales 1: $4.1 \%$ and Ciliate 1: $2.7 \%$ ), and two chlorophytes (M. pusilla 1: $45 \%$ and $M$. pusilla 2: $2.3 \%$ ). HG4 showed greater diversity, with four stramenopiles (Chrysophyte 1: 4\%, MAST I: $1.2 \%$, MAST III: $1.2 \%$, and B. pacifica: $1.3 \%$ ), four alveolates (Syndiniales 1: 1.5\%, Syndiniales 2: 2.3\%, Ciliate 1: $1.9 \%$, and an undefined Alveolate: $6 \%$ ), and two chlorophytes (M. pusilla 1: $6.2 \%$ and $M$. pusilla 2: $2.7 \%$ ). At HGN4, no stramenopiles but six alveolate phylotypes (one undefined Dinophyte: 22.4\%, Prorocentrales 1: $2.1 \%$, Gymnodiniales 2: 1.6\%, Syndiniales 1: 1.2\%. Syndiniales 3: $1.2 \%$, and Ciliate 1: $1.3 \%$ ) and two unclassified phylotypes, labeled as undefined Eukaryote 1 and 2 were recovered. The abundant biosphere at the final station, HGS3, comprised six additional phylotypes, divided into one stramenopile phylotype (undef. Pelagophyte: 1.9\%), two alveolate phylotypes (Gymnodiniales 1: 1.5\% and Syndiniales 4:1.1\%), two chlorophyte phylotypes (M. pusilla 1: $6.3 \%$ and M. pusilla 2: $2 \%$ ), and one undefined eukaryote. In general, we observed dominance of Micromonas at HG1, of Dinophyte 1 at HGN4, and of Phaeocystis at HG4 and HGS3.

\section{Evaluation of sequential filtration quality}

We investigated phylotype overlaps between the analyzed size fractions at one station, to investigate the suggestion that cell breakage or squeezing of flexible cells during the fractionation process might reduce the accuracy of picoplankton diversity studies. Sequencing of the three different size classes $(\geq 10 \mu \mathrm{m}, 10$ to $3 \mu \mathrm{m}, 3$ to $0.4 \mu \mathrm{m})$ resulted in strongly differing sequencing depths. While sequencing of the biggest (microplankton) and middle (nanoplankton) size filter resulted in similar read numbers of 24,964 , sequencing of the smallest (picoplankton) filter resulted in 9,830 reads. Quality filtering removed between 37 ( 3 to $0.4 \mu \mathrm{m}$ ) and $79 \%(\geq 10 \mu \mathrm{m})$ of the initial reads (Table 2). Subsampling was carried out to the minimum sequence number $(3,966)$, recovered in the picoplankton fraction. Subsequent clustering of the 3,966 sequences in each size class, on a $97 \%$ similarity threshold, presented 277 OTUs for the smallest size filter, 216 OTUs for the middle size filter, and 240 OTUs for the biggest size filter.

Figure 3 is a Venn diagram, showing the overlaps of OTUs between the three size classes. The micro- and nanoplankton classes shared a total of 26 OTUs. The nano- and picoplankton shared 14 . The micro- and picoplankton shared 13. 19 OTUs were found in all three size classes. Numbers of unshared OTUs were greatest for the picoplankton (231), followed by the microplankton (182) and nanoplankton (157). A detailed apportionment, including the identities of shared OTUs, is presented in Table S1. Of the 19 ubiquitous OTUs, only five were parts of the abundant biosphere $>1 \%$ of the total sequence reads) while the residual OTUs contributed less than $0.5 \%$ to the total picoplankton assemblages. The five OTUs were classified as $P$. pouchetii, B. pacifica, Prorocentrum

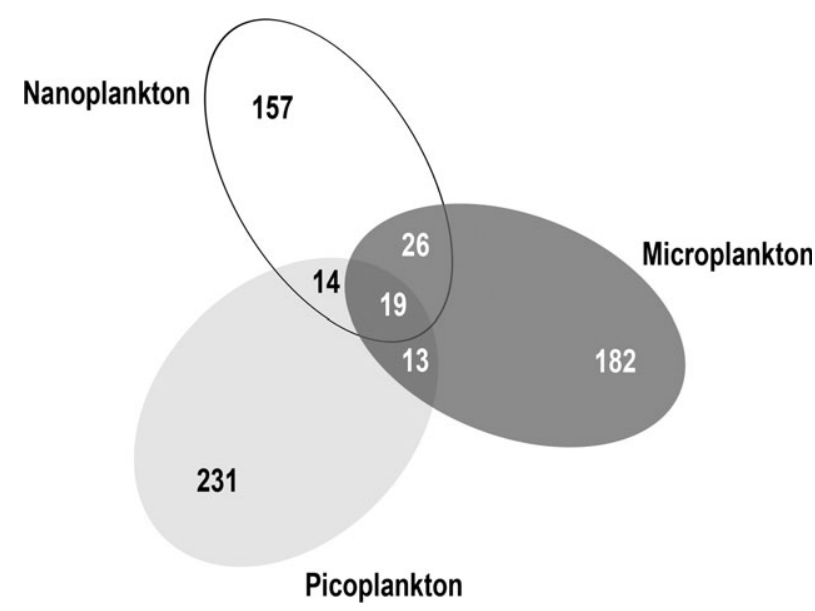

Figure 3 Venn diagram of OTU intersections between the three different size classes (> $10 \mu \mathrm{m}, 10$ to $3 \mu \mathrm{m}$ and 3 to $0.4 \mu \mathrm{m})$. OTUs were generated after subsampling and under a threshold of $97 \%$. 
micans, one undefined Gymnodiniaceae, and one Syndiniales. Two OTUs, identified as M. pusilla and a member of the Syndiniales group, were shared by the micro- and picoplankton fractions and presented abundant portions of $4.8 \%$ and $2 \%$ in the picoplankton. Likewise, two OTUs were found in the nano- and picoplankton fractions with abundant contributions of $3.1 \%$ (M. pusilla) and $1.2 \%$ (marine stramenopile; MAST). No diatom phylotype was recovered in the picoplankton size fraction.

\section{DISCUSSION}

The objective of this study was to investigate the picoeukaryote population west of Spitsbergen, where molecular data are scarce and 454-pyrosequencing data are missing. 454-pyrosequencing has proven to make reliable environmental surveys of genetic diversity possible and is by now commonly used to study environmental samples (Cheung et al. 2010; Sogin et al. 2006; Stoeck et al. 2010). Our study of picoplankton genetic diversity west of Spitsbergen will serve as a baseline for future datasets. In the following, we use the data for a comparison with surveys of the picoplankton assemblage in the Canadian Basin (Beaufort Sea), where $M$. pusilla is most prominent. Since the sequential fractionation step can strongly bias picoplankton diversity studies because of cell breakage and squeezing of flexible cells, we assessed the phylotype overlap at one station to check the applicability of the low pressure utilized.

\section{PICOPLANKTON DIVERSITY}

On the basis of the foregoing quality check of the filtration procedure, we assume a largely pure picoplankton fraction. Phylotypes in both the abundant and rare biosphere could not all be taxonomically assigned in detail (to genus level) because of the absence of analogous sequences in the database. In such cases, the consensus sequence was assigned to the next higher nodal point in the phylogenetic tree. A prerequisite for a better representation of picoplankton species in databases would be the generation of clonal cultures. Picoplankton culturing however is a difficult task; some may be even unculturable (Massana 2011). By applying PhyloAssigner (Vergin et al. 2013), we were able to reliably assign picoplankton sequences at least to higher taxonomic levels and to assess how they were organized in taxonomic units. Although public databases may contain more picoplankton sequences, they are often deposited without taxonomic affiliation. In some occasions, different OTUs clustered within one reference species. This could be a result of different species strains or may suggest that different taxonomic groups require different diversity thresholds, because of wide intraspecific variances. A study of the intraspecific diversity of Alexandrium catenella (dinoflagellate) revealed a wide variance of $0-2.9 \%$ (Miranda et al. 2012), suggesting that other species may indeed comprise higher discrepancies as well.

Picoplankton community structures at all four stations differed strongly. They showed a dominance of dinoflagel- lates at HGN4, a dominance of chlorophytes at $\mathrm{HG} 1$ and a dominance of haptophytes at HG4 and HGS3. HG1 was located furthest east in the coldest and least saline water, without ice coverage. Differences in salinity and temperature can be attributed to the ESC that transports cold Arctic water from the Barents Sea to the west coast of Spitsbergen. In addition, freshwater from Kongsfjord might also have altered the abiotic characteristics to some extent. Micromonas pusilla dominated the abundant biosphere at HG1, followed by $B$. prasinos and $P$. pouchetii. Here, Micromonas was represented by two phylotypes, of which one ( $M$. pusilla 1 ) was particularly dominant, while the other (M. pusilla 2) was scarcer. The dominant phylotype grouped with the cold adapted, Arctic ecotype (CCMP2099) (Lovejoy et al. 2007), while the other could not be affiliated to a particular ecotype. Studies of the genetic diversity of Micromonas identified five clades $(A-E)$, in which one (Ea) consists exclusively of Arctic phylotypes (Lovejoy et al. 2007; Slapeta et al. 2006). Micromonas sp. 1 is part of the Arctic Ea clade, that contains strains of Micromonas sp. and grows faster under low light and low temperature conditions (Lovejoy et al. 2007). Previous studies observed a greater prevalence in Pacific Water influenced stations, characterized by lower salinity and temperature, than in the warmer and saltier AW stations (Brugel et al. 2009; Lovejoy et al. 2007; Not et al. 2005). The fact that HG1 was most likely influenced by Arctic water from the ESC supports the dominance of the Arctic Micromonas clade. In contrast, Not et al. (2004) showed that prasinophytes like Micromonas comprise large proportions of the picophytoplankton in marine coastal waters. Consistent with this, a study of the potential ecological niche apportionment of three different $M$. pusilla lineages observed high cell abundances of two lineages in coastal areas (Foulon et al. 2008). These observations support the dominance of Micromonas at the coastal influenced station HG1. We therefore assume that cold Arctic water and proximity to the West Spitsbergen coast influenced abiotic conditions and favored the growth of the cold-adapted phylotype.

HGN4 was located furthest north and was characterized by high salinity, warm temperature, and moderate ice coverage that limited the light penetration into the water column. The station was strongly influenced by $\mathrm{AW}$, with an average temperature of $3.52{ }^{\circ} \mathrm{C}$ and salinity of $34.7 \%$ (Montgomery 1958). Micromonas was absent from the abundant biosphere at HGN4, whereas the dinoflagellate proportion was at a maximum. Jakobsen and Hansen (1997) reported small dinoflagellates, but the minimal cell size of Gyrodinium sp., for example, ranged around $7 \mu \mathrm{m}$, in the nanoplankton range. Syndiniales, another dominant dinoflagellate group, is considered mainly to consist of picoplankton. It is thought that the order is solely marine and its species pass through picoplanktonic life stages (Guillou et al. 2008; Yih and Coats 2000). Further, it is assumed that Syndiniales are mostly parasitic, for example on other dinoflagellates (Groisillier et al. 2006; Guillou et al. 2008). The majority of dinoflagellate phylotypes in our study grouped within this order. 
Since, we found the highest percentages of Syndiniales at stations that also presented the overall highest proportions of dinoflagellates, we suggest that the Syndiniales phylotypes may consist of dinoflagellate parasites. In line with this, there was no Syndiniales phylotype in the abundant biosphere at HG1, where the dinoflagellate proportion was least. Overall, knowledge of picoplankton dinoflagellate diversity is incomplete. The existence of possible non-Syndiniales picoplankton can only be speculated on, both in Fram Strait and the Canadian Basin. Dinoflagellates employ a broad spectrum of nutritional strategies, including autotrophy, heterotrophy, and even mixotrophy. About half of the species are heterotrophic and show no plastids, while the other half is characterized by the presence of plastids and can be autotrophic or mixotrophic (Gomez 2012). The ice coverage, and thus limited light availability, at HGN4 doubtless support a predominance of heterotrophic or mixotrophic or parasitic species.

HG4, the most westerly located sampling site, showed lower temperature than at HGN4, but their salinity and ice conditions were comparable. The abundant biosphere at HG4 was characterized by a comparably high diversity of stramenopiles, for example as B. pacifica or MAST. Both are considered typical picoplankton representatives with cell sizes of $<2$ and $<5 \mu \mathrm{m}$ (Guillou et al. 1999a,b; Lin et al. 2012; Massana et al. 2006). Phylogenetic analysis presented different groups of marine stramenopiles with different distribution profiles. MAST I and MAST III are both suggested to be heterotrophic and were found in open sea areas as well as coastal waters (Massana et al. 2004a,b). The greatest abundances were recorded for $P$. pouchetii, most likely represented by solitary, flagellate cells. A dominance of such solitary cells and a minor proportion of colonial cells was previously found in spring/ early summer close to Svalbard (Wassmann et al. 2005). Our sampling was conducted in July and suggests the high abundance of solitary cells continues into mid-summer. Large quantities of $P$. pouchetii were reported in the Atlantic sector of the Arctic Ocean and the Barents Sea (Degerlund and Eilertsen 2010). In contrast, molecular surveys in the Bering Strait, Chukchi Sea and Beaufort Sea reported a relatively low abundance of haptophytes or $P$. pouchetii (Balzano et al. 2012; Lovejoy et al. 2011). The predominance of Phaeocystis in the Barents Sea was associated inter alia with the high salinity of AW (Rat'kova and Wassmann 2002; Reigstad et al. 2002). Consistent with this view, we recorded the highest proportions in the more saline sampling stations (HG4 and HGS3).

The southern station, HGS3 was similar to HGN4 in temperature and salinity, but ice-free. Overall, the community compositions of major taxonomic groups at HGS3, HG4, and HGN4 were similar. A more detailed examination of the abundant biosphere revealed a stronger similarity between HGS3 and HG4. Phaeocystis pouchetii was most abundant at HGS3 and accounted for similar percentages as at HG4. The two stations also presented similar proportions of Micromonas spp. The strong similarity of picoplankton community structures at HGS3 and HG4, in addition to their similarity to HGN4, suggests the WSC (AW) strongly moderates picoplankton dispersal. This suggestion is supported by other studies that reported a strong influence of water mass on microbial communities in general (Hamilton et al. 2008; Lovejoy and Potvin 2011; Lovejoy et al. 2006; Terrado et al. 2009). Varying water mass densities constitute physical boundaries to the dispersion of microbes, owing to their small size and planktonic lifestyle (Galand et al. 2009). This permits a scenario in which the investigated picoeukaryote assemblage was transported northwards by the WSC, undergoing modification en route by sea ice formation and water mass mixing.

In summary, most species in this study were allocated to the picoplankton, pointing to the reliability of fractionation during the filtration process. No metazoan or diatom phylotypes were found in the picoplankton dataset, and just one ciliate was recovered in the abundant biosphere. The picoplankton community in eastern Fram Strait was dominated by chlorophytes such as M. pusilla, haptophytes such as $P$. pouchetii, and dinoflagellates such as Syndiniales. Strong abundances of Micromonas at one station were related to the influence of Arctic Water (ESC), while the other stations were located in AW (WSC). This water mass-related distribution of picoeukaryotes is in line with other studies (Hamilton et al. 2008; Lovejoy et al. 2002). The dominance of Phaeocystis and Syndiniales in the WSC further suggests that the picoplankton of eastern Fram Strait is not exclusively dominated by the chlorophyte M. pusilla, in contrast to that in the East Canadian Arctic (Lovejoy et al. 2007). Considering the ongoing warming of the WSC, we assume that picoplankton communities in the Arctic Ocean may come to be altered by the introduction of distinct AW communities.

\section{Impact of sequential fractionation}

Numerous studies highlight the dangers of cell breakage, cell flexibility (possibly squeezing through filter pores), and sloppy zooplankton feeding for reliable presentation of picoplankton diversity (Massana et al. 2004b; Romari and Vaulot 2004). With this in mind, we assessed the quality of the filtration procedure at one single station, by comparing the distributions of OTUs over three size classes.

We first noticed a strong discrepancy in the raw sequence number of all three size fractions, with twice as many sequences yielded for the nano- and microplankton. These samples were part of a later sequencing run, leading us to suspect the discrepancy is a result of technological progress, with more sequences matching our quality criteria (e.g. $>300$ bp).

Furthermore, we observed little concurrence in OTUs shared between the picoplankton and the other two size classes. Only $\sim 17 \%$ (Fig. 3) of the recovered OTUs in the picoplankton fraction were also found in the nanoplankton and/or the microplankton fractions. Focusing on the abundant biosphere (15 OTUs of which 12 matched a reference sequence in the database), just eight OTUs were shared between the picoplankton and another fraction. 
Two of these ( $P$. micans and a Gymnodiniaceae phylotype) potentially originate from nonpicoplankton species, and so might constitute artifacts of cell breakage that would upwardly bias the diversity analysis of picoplankton species. To date, the known minimum size of dinoflagellates and ciliates is 5-10 $\mu \mathrm{m}$ (Massana 2011). The presence of single phylotypes in all size fractions could be interpreted in terms of unknown small dinoflagellates, or in terms of cell breakage or free dissolved DNA (Massana et al. 2004a). Dinoflagellates are often reported to cover a wide cell size spectrum, including all three size fractions and dominating in the nano- and microplankton (Levinsen et al. 1999; Silva and Faust 1995). The presence of various sized cell stages in the life cycle of dinoflagellates (e.g. Gymnodiniales: Figueroa et al. 2008), makes it difficult to make clear statements on the possibility of cell breakage. Overall, knowledge about picoplanktonic dinoflagellates is limited. Species are supposed mainly to be parasitic Syndiniales phylotypes (Guillou et al. 2008). Consistent with this, unique dinoflagellate phylotypes in our picoplankton fraction mostly affiliate to the Syndiniales.

The majority of multiply occurring phylotypes in the abundant biosphere, however, were assigned to known typical picoplankton representatives, such as M. pusilla, MAST or Syndiniales. Micromonas pusilla is one of the most prominent picoeukaryotes, with a worldwide distribution (Eikrem and Throndsen 1990; Lovejoy et al. 2007; Rodriguez et al. 2005; Throndsen and Kristiansen 1991). Similarly, marine stramenopiles (MAST) have often been reported in picoplankton studies, where they represent a significant fraction of the heterotrophic flagellates (Lin et al. 2012; Massana et al. 2004b, 2006). The size range, 2-5 $\mu \mathrm{m}$ (Massana et al. 2004b), also covers nanoplanktonic cells. The observation that sequences affiliated to well known picoplankton taxa were also recovered in bigger fractions suggests that small cells might be attached to bigger size cells throughout the filtration process, or that these cells form aggregates. This is not surprising for parasitic Syndiniales cells that have been reported in a great variety of marine hosts, including dinoflagellates, radiolarians, ciliates, crabs, or copepod eggs (Groisillier et al. 2006). The size of $P$. pouchetii cells, which account for one third of the total picoplankton sequences and was found in all size fractions, is a complex attribute. Phaeocystis pouchetii passes through a life cycle with stages as small free-living cells a few microns in diameter (nanoplankton), and colonies millimeters in diameter (microplankton) (Gaebler-Schwarz et al. 2010; Rousseau et al. 2007). The fact that picoplankton phylotypes were recovered in the microplankton but not in the nanoplankton is possibly an artifact of removal of single cells by disruption of cell aggregates during the first filtration. The larger surface area of microplankton cells likely favored the accumulation of picoplankton cells.

Potential evidence for cell breakage was found in the recovery of ciliates in the picoplankton fraction. These observations were scarce and accounted for small percentages $(<0.5 \%)$ in the filtration bias approach but greater percentages in the picoplankton diversity approach, including one abundant phylotype (Ciliate 1). Ciliates are important contributors to the microplankton (Perez et al. 2000). Representative species, such as Strombidium sp. or Strobilidium sp., cover cell sizes of

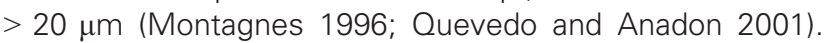
Some studies have reported the presence of ciliates in picoplankton assemblages (Cheung et al. 2008; Medlin et al. 2006; Romari and Vaulot 2004; Worden 2006). These observations are thought to be most likely artifacts of cell breakage because of the ciliates' fragile nature. The fact that ciliates, and no diatoms, were recovered in the picoplankton fraction leads us to the conclusion that the robust shells of diatoms prevent cell breakage at 200 mbar, while the naked ciliates are more sensitive to the filtration procedure. Another explanation for the discovery of micro- or nanoplankton phylotypes in picoplankton studies could be the amplification of extracellular DNA, as often observed in bacteria diversity studies (Pawlowski et al. 2011).

In summary, overlap of OTUs over all three or pairs of size classes was relatively slight, suggesting an adequate filtering procedure at 200 mbar low pressure, in which cell breakage did not greatly impact the picoplankton fraction. No diatom cells were found in the picoplankton although they were abundant in the microplankton. We still have to keep in mind that the presence of multiple cell stages during protist life cycles (e.g. of dinoflagellates and Phaeocystis sp.) and the limited knowledge of real picoeukaryotic representatives leave it difficult to make definitive statements about filtration bias. Moreover, as the investigation of potential filtration biases was limited to one station, it can only serve as a rough guide for processing material from the other stations by supporting the low pressure used. We further showed that small cells, such as Micromonas and Syndiniales have the potential to bias the nano and microplankton fraction.

\section{ACKNOWLEDGMENT}

This study was accomplished within the Young Investigator Group PLANKTOSENS (VH-NG-500), funded by the Initiative and Networking Fund of the Helmholtz Association. We thank the captain and crew of the RV Polarstern for their support during the cruise ARKXXIV/2. We are especially indebted to F. Kilpert and B. Beszteri for their support in bioinformatics and very grateful to A. Schröer, A. Nicolaus, and K. Oetjen for excellent technical support in the laboratory.

\section{LITERATURE CITED}

Atkinson, D. 1994. Temperature and organism size - a biological law for ectotherms? Adv. Ecol. Res., 25:1-58.

Atkinson, D., Ciotti, B. J. \& Montagnes, D. J. S. 2003. Protists decrease in size linearly with temperature: ca. $2.5 \%$ degrees $C$ 1. Proc. R Soc. B Biol. Sci., 270:2605-2611.

Balzano, S., Marie, D., Gourvil, P. \& Vaulot, D. 2012. Composition of the summer photosynthetic pico and nanoplankton communities in the Beaufort Sea assessed by T-RFLP and sequences of 
the $18 \mathrm{~S}$ rRNA gene from flow cytometry sorted samples. ISME J., 6:1480-1498.

Behnke, A., Engel, M., Christen, R., Nebel, M., Klein, R. R. \& Stoeck, T. 2011. Depicting more accurate pictures of protistan community complexity using pyrosequencing of hypervariable SSU rRNA gene regions. Environ. Microbiol., 13: 340349.

Beszczynska-Möller, A., Fahrbach, E., Schauer, U. \& Hansen, E. 2012. Variability in Atlantic water temperature and transport at the entrance to the Arctic Ocean, 1997-2010. ICES J. Mar. Sci., 69:852-863.

Bopp, L., Aumont, O., Cadule, P., Alvain, S. \& Gehlen, M. 2005. Response of diatoms distribution to global warming and potential implications: a global model study. Geophys. Res. Lett., 32: L19606. doi:10.1029/2005gl023653.

Brugel, S., Nozais, C.-, Poulin, M., Tremblay, J. E., Miller, L. A., Simpson, K. G., Gratton, Y. \& Demers, S. 2009. Phytoplankton biomass and production in the southeastern Beaufort Sea in autumn 2002 and 2003. Mar. Ecol. Prog. Ser., 377:63-77.

Cheung, M. K., Chu, K. H., Li, C. P., Kwan, H. S. \& Wong, C. K. 2008. Genetic diversity of picoeukaryotes in a semi-enclosed harbour in the subtropical western Pacific Ocean. Aquat. Microb. Ecol., 53:295-305.

Cheung, M. K., Au, C. H., Chu, K. H., Kwan, H. S. \& Wong, C. K. 2010. Composition and genetic diversity of picoeukaryotes in subtropical coastal waters as revealed by 454 pyrosequencing. ISME J., 4:1053-1059.

Comeau, A. M., Philippe, B., Thaler, M., Gosselin, M., Poulin, M. \& Lovejoy, C. 2013. Protists in Arctic drift and land-fast sea ice. J. Phycol., 49:229-240.

Countway, P. D. \& Caron, D. A. 2006. Abundance and distribution of Ostreococcus sp in the San Pedro Channel, California, as revealed by quantitative PCR. Appl. Environ. Microbiol., 72:2496-2506.

Daufresne, M., Lengfellner, K. \& Sommer, U. 2009. Global warming benefits the small in aquatic ecosystems. Proc. Natl Acad. Sci. USA, 106:12788-12793.

Degerlund, M. \& Eilertsen, H. C. 2010. Main species characteristics of phytoplankton spring blooms in NE Atlantic and Arctic waters (68-80A degrees N). Estuar. Coasts, 33:242-269.

Diez, B., Pedros-Alio, C. \& Massana, R. 2001. Study of genetic diversity of eukaryotic picoplankton in different oceanic regions by small-subunit rRNA gene cloning and sequencing. Appl. Environ. Microbiol., 67:2932-2941.

Edgar, R. C., Haas, B. J., Clemente, J. C., Quince, C. \& Knight, R. 2011. UCHIME improves sensitivity and speed of chimera detection. Bioinformatics, 27:2194-2200.

Eikrem, W. \& Throndsen, J. 1990. The ultrastructure of Bathycoccus gen-nov and <bathycoccus prasinos sp-nov, a nonmotile picoplanktonic alga (Chlorophyta, Prasinophyceae) from the Mediterranean and Atlantic. Phycologia, 29:344-350.

Elwood, H. J., Olsen, G. J. \& Sogin, M. L. 1985. The small-subunit roibosomal RNA gene sequences from the hypotrichous ciliates oxytrichia nova and Stylonychia pustulata. Mol. Biol. Evol., 2:399-410

Figueroa, R. I., Bravo, I., Ramilo, I., Pazos, Y. \& Morono, A. 2008. New life-cycle stages of Gymnodinium catenatum (Dinophyceae): laboratory and field observations. Aquat. Microb. Ecol., 52:13-23.

Foulon, E., Not, F., Jalabert, F., Cariou, T., Massana, R. \& Simon, N. 2008. Ecological niche partitioning in the picoplanktonic green alga Micromonas pusilla: evidence from environmental surveys using phylogenetic probes. Environ. Microbiol., 10:2433-2443.
Gaebler-Schwarz, S., Davidson, A., Assmy, P., Chen, J. X., Henjes, J., Nothig, E. M., Lunau, M. \& Medlin, L. K. 2010. A new cell stage in the haploid-diploid life cycle of the colony-forming haptophyte Phaeocystis antarctica and ist ecological implications. J. Phycol., 46:1006-1016.

Galand, P. E., Casamayor, E. O., Kirchman, D. L. \& Lovejoy, C. 2009. Ecology of the rare microbial biosphere of the Arctic Ocean. Proc. Natl Acad. Sci. USA, 106:22427-22432.

Gaspar, J. M. \& Thomas, W. K. 2013. Assessing the consequences of denoising marker-based metagenomic data. PLOS ONE, 8:e60458. doi:10.1371/journal.pone.0060458.

Gomez, F. 2012. A quantitative review of the lifestyle, habitat and trophic diversity of dinoflagellates (Dinoflagellata, Alveolata). Syst. Biodivers., 10:267-275.

Groisillier, A., Massana, R., Valentin, K., Vaulot, D. \& Guillou, L. 2006. Genetic diversity and habitats of two enigmatic marine alveolate lineages. Aquat. Microb. Ecol., 42:277-291.

Guillou, L., Chretiennot-Dinet, M. J., Medlin, L. K., Claustre, H., Loiseaux-de Goer, S. \& Vaulot, D. 1999a. Bolidomonas: a new genus with two species belonging to a new algal class, the Bolidophyceae (Heterokonta). J. Phycol., 35:368-381.

Guillou, L., Moon-Van Der Staay, S. Y., Claustre, H., Partensky, F. \& Vaulot, D. 1999b. Diversity and abundance of bolidophyceae (Heterokonta) in two oceanic regions. Appl. Environ. Microbiol., 65:4528-4536.

Guillou, L., Viprey, M., Chambouvet, A., Welsh, R. M., Kirkham, A. R., Massana, R., Scanlan, D. J. \& Worden, A. Z. 2008. Widespread occurrence and genetic diversity of marine parasitoids belonging to Syndiniales (Alveolata). Environ. Microbiol., 10:3349-3365.

Hamilton, A. K., Lovejoy, C., Galand, P. E. \& Ingram, R. G. 2008. Water masses and biogeography of picoeukaryote assemblages in a cold hydrographically complex system. Limnol. Oceanogr., 53:922-935.

Huse, S. M., Dethlefsen, L., Huber, J. A., Welch., D. M., Relman, D. A. \& Sogin, M.L. 2008. Exploring microbial diversity and taxonomy using SSU rRNA hypervariable tag sequencing. PLOS Genet. 4, e1000255. doi: 10.1371/journal.pgen.1000255

Ishizaka, J., Harada, K., Ishikawa, K., Kiyosawa, H., Furusawa, H., Watanabe, Y., Ishida, H., Suzuki, K., Handa, N. \& Takahashi, M. 1997. Size and taxonomic plankton community structure and carbon flow at the equator, 175 degrees $E$ during 1990-1994. Deep Sea Res. Part II Top Stud. Oceanogr., 44: 1927-1949.

Jakobsen, H. H. \& Hansen, P. J. 1997. Prey size selection, grazing and growth response of the small heterotrophic dinoflagellate Gymnodinium sp. and the ciliate Balanion comatum - a comparative study. Mar. Ecol. Prog. Ser., 158:75-86.

Kilias, E., Wolf, C., Nöthig, E. M., Peeken, I. \& Metfies, K. 2013. Protist distribution in the Western Fram Strait in summer 2010 based on 454-pyrosequencing of 18S rDNA. J. Phycol., 49:9961010.

Kunin, V., Engelbrektson, A., Ochman, H. \& Hugenholtz, P. 2010. Wrinkles in the rare biosphere: pyrosequencing errors can lead to artificial inflation of diversity estimates. Environ. Microbiol., 12:118-123.

Levinsen, H., Nielsen, T. G. \& Hansen, B. W. 1999. Plankton community structure and carbon cycling on the western coast of Greenland during the stratified summer situation. II. Heterotrophic dinoflagellates and ciliates. Aquat. Microb. Ecol., 16:217232.

Li, W. K. W. 2009. From cytometry to macroecology: a quarter century quest in microbial oceanography. Aquat. Microb. Ecol., 57:239-251. 
Li, W. K. W., McLaughlin, F. A., Lovejoy, C. \& Carmack, E. C. 2009. Smallest algae thrive as the Arctic Ocean freshens. Science, 326:539.

Lin, Y. C., Campbell, T., Chung, C. C., Gong, G. C., Chiang, K. P. \& Worden, A. Z. 2012. Distribution patterns and phylogeny of marine stramenopiles in the north pacific ocean. Appl. Environ. Microbiol., 78:3387-3399.

Lopez-Garcia, P., Rodriguez-Valera, F., Pedros-Alio, C. \& Moreira, D. 2001. Unexpected diversity of small eukaryotes in deep-sea Antarctic plankton. Nature, 409:603-607.

Lovejoy, C., Legendre, L., Martineau, M. J., Bacle, J. \& von Quillfeldt, C. H. 2002. Distribution of phytoplankton and other protists in the North Water. Deep Sea Res. Part II, 49:5027-5047.

Lovejoy, C., Price, N. M. \& Legendre, L. 2004. Role of nutrient supply and loss in controlling protist species dominance and microbial food-webs during spring blooms. Aquat. Microb. Ecol., 34:79-92

Lovejoy, C., Massana, R. \& Pedros-Alio, C. 2006. Diversity and distribution of marine microbial eukaryotes in the Arctic Ocean and adjacent seas. Appl. Environ. Microbiol., 72: 3085-3095.

Lovejoy, C., Vincent, W. F., Bonilla, S., Roy, S., Martineau, M. J., Terrado, R., Potvin, M., Massana, R. \& Pedros-Alio, C. 2007. Distribution, phylogeny, and growth of cold-adapted picoprasinophytes in arctic seas. J. Phycol., 43:78-89.

Lovejoy, C. \& Potvin, M. 2011. Microbial eukaryotic distribution in a dynamic Beaufort Sea and the Arctic Ocean. J. Plankton Res., 33:431-444.

Lovejoy, C., Galand, P. E. \& Kirchman, D. L. 2011. Picoplankton diversity in the Arctic Ocean and surrounding seas. Mar. Biodiv., 41:5-12.

Marin, B. \& Melkonian, M. 2010. Molecular phylogeny and classification of the Mamiellophyceae class. nov (Chlorophyta) based on sequence comparisons of the nuclear- and plastid-encoded rRNA operons. Protist, 161:304-336.

Massana, R., Balague, V., Guillou, L. \& Pedros-Alio, C. 2004a. Picoeukaryotic diversity in an oligotrophic coastal site studied by molecular and culturing approaches. FEMS Microbiol. Ecol., 50:231-243.

Massana, R., Castresana, J., Balague, V., Guillou, L., Romari, K., Groisillier, A., Valentin, K. \& Pedros-Alio, C. 2004b. Phylogenetic and ecological analysis of novel marine stramenopiles. Appl. Environ. Microbiol., 70:3528-3534.

Massana, R., Terrado, R., Forn, I., Lovejoy, C. \& Pedros-Alio, C. 2006. Distribution and abundance of uncultured heterotrophic flagellates in the world oceans. Environ. Microbiol., 8:1515-1522.

Massana, R. 2011. Eukaryotic Picoplankton in Surface Oceans. In: Gottesman, S. \& Harwood, C. S. (ed.), Annual Reviews. Annual Review of Microbiology, Vol. 65. Palo Alto. p. 91-110.

Medinger, R., Nolte, V., Pandey, R. V., Jost, S., Ottenwalder, B., Schlotterer, C. \& Boenigk, J. 2010. Diversity in a hidden world: potential and limitation of next-generation sequencing for surveys of molecular diversity of eukaryotic microorganisms. Mol. Ecol., 19:32-40.

Medlin, L. K., Metfies, K., Mehl, H., Wiltshire, K. \& Valentin, K. 2006. Picoeukaryotic plankton diversity at the Helgoland time series site as assessed by three molecular methods. Microb. Ecol., 52:53-71.

Miranda, L. N., Zhuang, Y. Y., Zhang, H. \& Lin, S. 2012. Phylogenetic analysis guided by intragenomic SSU rDNA polymorphism refines classification of "Alexandrium tamarense" species complex. Harmful Algae, 16:35-48.

Montagnes, D. J. S. 1996. Growth responses of planktonic ciliates in the genera Strobilidium and Strombidium. Mar. Ecol. Prog. Ser., 130:241-254.
Montgomery, R. B. 1958. Water characteristics of Atlantic Ocean and of world ocean. Deep Sea Res., 5:134-148.

Moon-van der Staay, S. Y., De Wachter, R. \& Vaulot, D. 2001. Oceanic 18S rDNA sequences from picoplankton reveal unsuspected eukaryotic diversity. Nature, 409:607-610.

Moran, X. A. G., Lopez-Urrutia, A., Calvo-Diaz, A. \& Li, W. K. W. 2010. Increasing importance of small phytoplankton in a warmer ocean. Glob. Change Biol., 16:1137-1144.

Nickrent, D. L. \& Sargent, M. L. 1991. An overview of the secondary structure of the V4 region of eukaryotic small-subunit ribosomal RNA. Nucleic Acid Res., 19:227-235.

Not, F., Latasa, M., Marie, D., Cariou, T., Vaulot, D. \& Simon, N. 2004. A single species, Micromonas pusilla (Prasinophyceae), dominates the eukaryotic picoplankton in the western English channel. Appl. Environ. Microbiol., 70:4064-4072.

Not, F., Massana, R., Latasa, M., Marie, D., Colson, C., Eikrem, W., Pedros-Alio, C., Vaulot, D. \& Simon, N. 2005. Late summer community composition and abundance of photosynthetic picoeukaryotes in Norwegian and Barents Seas. Limnol. Oceanogr., 50:1677-1686.

Not, F., del Campo, J., Balague, V., de Vargas, C. \& Massana, R. 2009. New insights into the diversity of marine picoeukaryotes. PLOS ONE, 4:e7143. doi:10.1371/journal.pone.0007143.

Pawlowski, J., Christen, R., Lecroq, B., Bachar, D., Shahbazkia, H. R., Amaral-Zettler, L. \& Guillou, L. 2011. Eukaryotic richness in the abyss: insights from pyrotag sequencing. PLOS ONE, 6 : e18169. doi:10.1371/journal.pone.0018169.

Perez, M. T., Dolan, J. R., Vidussi, F. \& Fukai, E. 2000. Diel vertical distribution of planktonic ciliates within the surface layer of the NW Mediterranean (May 1995). Deep Sea Res. Part I, 47: 479-503.

Peter, K. H. \& Sommer, U. 2012. Phytoplankton cell size: intraand interspecific effects of warming and grazing. PLOS ONE, 7: e49632. doi:10.1371/journal.pone.0049632.

Potvin, M. \& Lovejoy, C. 2007. Comparisons of inshore and offshore arctic marine picoeukaryotes. J. Phycol., 43:160.

Pruesse, E., Quast, C., Knittel, K., Fuchs, B. M., Ludwig, W. G., Peplies, J. \& Glockner, F. O. 2007. SILVA: a comprehensive online resource for quality checked and aligned ribosomal RNA sequence data compatible with ARB. Nucleic Acids Res., 35:7188-7196.

Quevedo, M. \& Anadon, R. 2001. Protist control of phytoplankton growth in the subtropical north-east Atlantic. Mar. Ecol. Prog. Ser., 221:29-38.

Rat'kova, T. N. \& Wassmann, P. 2002. Seasonal variation and spatial distribution of phyto- and protozooplankton in the central Barents Sea. J. Mar. Syst., 38:47-75.

Reigstad, M., Wassmann, P., Riser, C. W., Oygarden, S. \& Rey, F. 2002. Variations in hydrography, nutrients and chlorophyll a in the marginal ice-zone and the central Barents Sea. J. Mar. Syst., 38:9-29.

Richardson, T. L. \& Jackson, G. A. 2007. Small phytoplankton and carbon export from the surface ocean. Science, 315:838840.

Rodriguez, F., Derelle, E., Guillou, L., Le Gall, F., Vaulot, D. \& Moreau, H. 2005. Ecotype diversity in the marine picoeukaryote Ostreococcus (Chlorophyta, Prasinophyceae). Environ. Microbiol., 7:853-859.

Romari, K. \& Vaulot, D. 2004. Composition and temporal variability of picoeukaryote communities at a coastal site of the English Channel from 18S rDNA sequences. Limnol. Oceanogr., 49:784-798.

Rousseau, V., Chretiennot-Dinet, M. J., Jacobsen, A., Verity, P. \& Whipple, S. 2007. The life cycle of Phaeocystis: state of knowl- 
edge and presumptive role in ecology. Biogeochemistry, 83:2947.

Schauer, U., Fahrbach, E., Osterhus, S. \& Rohardt, G. 2004. Arctic warming through the Fram Strait: oceanic heat transport from 3 years of measurements. J. Geophys. Res. Oceans, 109: C06026. doi:10.1029/2003jc001823.

Sieburth, J. M., Smetacek, V. \& Lenz, J. 1978. Pelagic ecosystem structure - heterotrophic compartments of plankton and their relationship to plankton size fractions - Comment. Limnol. Oceanogr., 23:1256-1263.

Silva, E. S. \& Faust, M. A. 1995. Small cells in the life-history of dinoflagellates (Dinophyceae) - a review. Phycologia, 34:396408.

Simon, N., Barlow, R. G., Marie, D., Partensky, F. \& Vaulot, D. 1994. Characterization of oceanic photosynthetic picoeukaryotes by flow cytometry. J. Phycol., 30:922-935.

Slapeta, J., Lopez-Garcia, P. \& Moreira, D. 2006. Global dispersal and ancient cryptic species in the smallest marine eukaryotes. Mol. Biol. Evol., 23:23-29.

Sogin, M. L., Morrison, H. G., Huber, J. A., Mark Welch, D., Huse, S. M., Neal, P. R., Arrieta, J. M. \& Herndl, G. J. 2006. Microbial diversity in the deep sea and the underexplored "rare biosphere". Proc. Natl Acad. Sci. USA, 103:12115-12120.

Soltwedel, T., Hasemann, C., Queric, N. V. \& von Juterzenka, K. 2005. Gradients in activity and biomass of the small benthic biota along a channel system in the deep Western Greenland Sea. Deep Sea Res., 52: 815-835.

Stoeck, T., Bass, D., Nebel, M., Christen, R., Jones, M. D. M., Breiner, H. W. \& Richards, T. A. 2010. Multiple marker parallel tag environmental DNA sequencing reveals a highly complex eukaryotic community in marine anoxic water. Mol. Ecol., 19:21-31.

Terrado, R., Vincent, W. F. \& Lovejoy, C. 2009. Mesopelagic protists: diversity and succession in a coastal Arctic ecosystem. Aquat. Microb. Ecol., 56:25-39.

Throndsen, J. \& Kristiansen, S. 1991. Micromonas pusilla (Prasinophyceae) as part of picoplankton and nanoplankton communities of the Barents Sea. Polar Res., 10:201-207.

Vaulot, D., Eikrem, W., Viprey, M. \& Moreau, H. 2008. The diversity of small eukaryotic phytoplankton $(\leq 3 \mu \mathrm{m})$ in marine ecosystems. FEMS Microbiol. Rev., 32:795-820.
Veldhuis, M. J. W., Cucci, T. L. \& Sieracki, M. E. 1997. Cellular DNA content of marine phytoplankton using two new fluorochromes: taxonomic and ecological implications. J. Phycol., 33:527-541.

Veldhuis, M. J. W., Timmermans, K. R., Croot, P. \& van der Wagt, B. 2005. Picophytoplankton; a comparative study of their biochemical composition and photosynthetic properties. J. Sea Res., 53:7-24.

Vergin, K. L., Beszteri, B., Monier, A., Thrash, J. C., Temperton, B., Treusch, A. H., Kilpert, F., Worden, A. Z. \& Giovannoni, S. J. 2013. High-resolution SAR11 ecotype dynamics at the Bermuda Atlantic Time-series Study site by phylogenetic placement of pyrosequences. ISME J., 7:1322-1332.

Wassmann, P., Ratkova, T. \& Reigstad, M. 2005. The contribution of single and colonial cells of Phaeocystis pouchetii to spring and summer blooms in the north-eastern North Atlantic. Harmful Algae, 4:823-840.

Whitman, W. B., Coleman, D. C. \& Wiebe, W. J. 1998. Prokaryotes: the unseen majority. Proc. Natl Acad. Sci. USA, 95:65786583.

Worden, A. Z. 2006. Picoeukaryote diversity in coastal waters of the Pacific Ocean. Aquat. Microb. Ecol., 43:165-175.

Yih, W. \& Coats, D. W. 2000. Infection of Gymnodinium sanguineum by the dinoflagellate Amoebophrya sp.: effect of nutrient environment on parasite generation time, reproduction, and infectivity. J. Eukaryot. Microbiol., 47:504-510.

\section{SUPPORTING INFORMATION}

Additional Supporting Information may be found in the online version of this article:

Table S1. Overview of the distribution of abundant phylotypes $(\geq 1 \%)$ over three size classes $>10 \mu \mathrm{m}, 10$ to $3 \mu \mathrm{m}$ and 3 to $0.4 \mu \mathrm{m}$, their taxonomic affiliation in the NCBI data base $(E$-value $=0)$ and their taxonomic affiliation after PhyloAssigner. Values are given in percent. Uc. $=$ uncultured. 